\title{
Use of Technical Diagnostics Means in Industrial Practice
}

Marián Výžinkár, Dominik Gašparovič, Jozef Žarnovský, Ivan Kováč, Rastislav Bernát

Faculty of Engineering, Slovak University of Agriculture in Nitra. Tr. A. Hlinku 2, 94976 Nitra. Slovak Republic. Email: xvyzinkar@is.uniag.sk, xgasparovic@is.uniag.sk,jozef.zarnovsky@uniag.sk, ivan.kovac@uniag.sk, rastislav.bernat@uniag.sk

Use of means of technical diagnostics gains in today's period increasing importance in all areas of industrial activity. Due to the tightening of the limits, software and hardware solutions improving is the diagnosis of the building one of the most important area in manufacturing and non-manufacturing organizations. The aim of the article is to clarify the possibility of using diagnostic procedures in the form of georadar to monitoring of location and status of reinforcement in a ferroconcrete bearing wall. For measuring was used radar system Mala CX12 with accessoriesand based on selected aspects has been diagnosed the exact location and status of the construction reinforcement. The result of this monitoring is to detect variations in the position of reinforcement and recorded corrosive damage. We investigated the humidity of concrete wall through the diffusion of EM waves while the evident product of decrease of the diffusion speed was the increased moisture of structure.The main outcome is to propose corrective measures in the form of the concrete carrying wall remediation necessity, as indicated by the results of this monitoring. By early use of the diagnostic means in the form of monitoring using georadar, it is possible to prevent the economic and environmental impacts.

Keywords: diagnostics, georadar, model, monitoring

\section{References}

[1] ALEŠ, Z., PAVLŮ, J., MÜller, M., SVOBODOVÁ, J., LEBEDEV, A., YUROV, A., PEXA, M., LINDA, M. (2016). Influence of Abrasive - Free Ultrasonic Finishing Process of Steel on Wear. In: Manufacturing Technology, 16 (1), ISSN 1213-2489, pp. 4-12.

[2] ALEŠ, Z., PEXA, M., PETERKA, B., HOLEK, M. (2010). Compressor maintenance supported by tribodiagnostics. In: Manufacturing Technology, vol. X., ISSN 1213-2489, pp. 87 - 93

[3] KREIDL, M. (2001). Diagnostické systémy. Prague: Czech technical university in Prague. 352 pp. ISBN 80-0102349-4.

[4] MIDOR, K. (2014). An analysis of the causes of product defects using quality management tools. In: Management Systems in Production Engineering, 4(16). pp. 162-167. DOI 10.12914/MSPE-04-04-2014.

[5] PEŤKOVÁ, V.(2010). Teória a aplikácia vybraných metód technickej diagnostiky. Technical university in Košice, pp.44-45, ISBN 978-80-553-0483-0.

[6] RAECORENTS. (2016) [online]. Košice. Availabe on: http://www.raecorents.com/products/ndt/Mala-cx12/MALA-CX-System-man-2011-01.pdf.

[7] ZASADZIEŃ M., SZCZESSIAK B., MIDOR. K. (2013). The functioning of e-maintenance services in selected devices of the building industry. In: Management Systems in Production Engineering, 1(9), pp. 31-36.

[8] ŽARNOVSKÝ, J. - PEŤKOVÁ, V. - RUŽBARSKÝ, J. (2009). Diagnostika strojov a zariadení. Nitra: Slovak university of agriculture. ISBN 978-80552-0300-3.

[9] ŽARNOVSKÝ, J. (2013). Využitie moderných diagnostických metód na zabezpečenie prevádzkyschopnosti vybraného technologického zariadenia: inaugural dissertation. Nitra: Slovak university of agriculture. 